\title{
COTA RACIAL E JARGÃO POLLIIAL NA UNIVERSIDADE: PARA ONDE VAMOS?
}

\section{Celia Maria Marinho de Azevedo \\ Universidade Estadual de Campinas - Brasil}

O grande mérito do artigo de Marcos Chor Maio e Ricardo Ventura Santos é ter posto a nu o autoritarismo e o arbítrio que permeiam as políticas anti-racistas de teor diferencialista, no caso, as ações afirmativas centradas em cotas raciais. Mas, além disso, o texto nos convida a refletir sobre o papel das ciências humanas na difusão de práticas autoritárias e na reatualização de conceitos científicos racistas no imaginário social.

O caso UnB é, sem dúvida, emblemático das posturas autoritárias e arbitrárias que vêm acompanhando a implantação do sistema de ingresso por cota racial em universidades brasileiras. É emblemático porque em nenhum outro caso a lógica de se atribuir raça aos seres humanos foi desenvolvida até as suas últimas conseqüências e com tanta clareza. O sistema de autodefinição de raça pelo próprio candidato, ou mesmo do exame de fotografias para conferir a suposta raça assinalada pelo vestibulando, não chamou anteriormente tanta atenção, possivelmente porque a pessoa a quem se atribuía o poder de definir a raça era pouco visível. Além disso, houve quem se contentasse com a justificativa de que a raça - uma das invenções mais perversas da velha ciência do século XIX - estava agora a ser reinventada para fins anti-racistas e, por conseguinte, benéficos.

Mas, assim que a UnB instituiu o seu Tribunal das Raças para coibir a ação dos "fraudadores raciais", muitos franziram o cenho, preocupados possivelmente com as estranhas analogias que se poderiam traçar com práticas científico-políticas nazistas, ou com aquelas vigentes no sistema de apartheid da África do Sul, até tempos bem recentes. Afinal, a idéia de que doravante políticos e cientistas sociais associados possam classificar a população em raças, conferindo direitos de raça a uns em detrimento de outros, abre caminho para a institucionalização de mais uma violência em nossa sociedade, na medida em que se torna lícito o princípio da “discriminação positiva”. 
Ora, aqueles que defendem a cota racial bem podem contraargumentar aqui que violência institucionalizada é aquela que se tem praticado contra a população negra há séculos, a começar pelo tráfico de escravos da África. Com a abolição da escravidão em 1888, essa mesma violência ganhou nova roupagem nos termos de uma política imigrantista racista que promoveu a substituição nos postos de trabalho dos ex-escravos e seus descendentes pelos imigrantes brancos, saudados como membros da "raça superior”, “caucasiana” ou "ariana”. Mas, se é certo que o racismo institucional se implantou no país com requintes de perversidade, uma vez que discrimina racialmente sem nomear "raças", por que haveríamos de combatê-lo enredados no mesmo conceito que permitiu conferir legitimidade científica à discriminação de povos vistos como “diferentes” e inferiores ao padrão branco “caucasiano”? Qual é afinal o objetivo do anti-racismo: combater efetivamente o racismo por meio da desconstrução persuasiva do conceito de raça no imaginário social ou criar direitos de "raça", contribuindo para que esse mesmo conceito seja legitimado e perpetuado nas mais diversas práticas sociais?

Ao ler o relato pontual dos estranhos fatos que se passaram nesse Tribunal das Raças da UnB, a começar pela sua pretensão de "homologar" ou não candidaturas com base no exame dos considerados verdadeiros traços da "raça negra", lembrei-me do velhíssimo debate que lá pelos idos das décadas de 1970 e 1980 travavam os intelectuais inspirados pela rebeldia da juventude de 1968. Para que servem, afinal, as ciências humanas e a ciência em geral? Elas devem refletir sobre as coisas desse mundo, interpretando-as criticamente no sentido da transformação social, ou devem simplesmente se subsumir a elas para bem servir aos gostos e apetites dos aparatos políticos, policiais, empresariais?

Como muito bem desvendado nesse artigo de Maio e Santos, a resposta à pergunta acima, por parte dos intelectuais-ativistas das políticas de cota racial, seria que as ciências humanas devem se conformar com o senso comum presente nos jargões policiais. Assim, devemos de agora em diante aprender com esses cientistas sociais que "negro" é aquele que tem "lábios grossos, nariz chato e cabelo pixaim” e, é claro, tom de pele "preta”! É, portanto, com base nesses mesmos estereótipos legados pela "melhor" ciência do século XIX, e ainda hoje implantados nos meios policiais e nas mentes racistas, que as autoridades universitárias, assessoradas por 
professores, estudantes e militantes anti-racistas, têm implantado o sistema de cota racial no vestibular de universidades públicas e privadas.

Como historiadora eu diria que, tal como no caso dos antropólogos analisado por Maio e Santos, também os professores e pesquisadores de história não escapam hoje aos apelos político-militantes para que eles se tornem especialistas em raça. A defesa de uma reescrita da história, o que não seria nenhuma novidade entre historiadores que se formaram sob a dupla herança da escola dos Annales e da teoria crítica marxista, assume feições devastadoras quando se reduz à proposição de uma história de identidades.

Nessas histórias em separado, ou seja, a história do negro, história do branco, história do índio, etc., ganha a cena a visão autoritária de quem pretende que as suas próprias fronteiras militantes se imponham na pesquisa histórica, cegando o pesquisador para quaisquer possibilidades que não as identidades primordiais, fixas e imutáveis inventadas pelos velhos teóricos das raças e, hoje, tristemente ressuscitadas por uma corrente do antiracismo. 